\title{
Structured Physical Activity did not Affect the Body Fat Percentage among Gymnastics Studio Members
}

\author{
Pengaruh Aktivitas Fisik Terstruktur terhadap Persentase Lemak Tubuh pada Anggota Sanggar \\ Senam
}

\author{
Erina Febriani Widiastari ${ }^{*}$, Fatimah Eliana Taufik ${ }^{2}$, Diniwati Mukhtar ${ }^{3}$ \\ ${ }^{1}$ Faculty of Medicine, YARSI University, Jalan Letjen. Suprapto Kav.13, Cempaka Putih, Central Jakarta, Jakarta, Indonesia. \\ 2 Department of Internal Medicine, Faculty of Medicine, YARSI University, Jalan Letjen. Suprapto Kav.13, Cempaka Putih, \\ Central Jakarta, Jakarta, Indonesia. \\ ${ }^{3}$ Department of Physiology, Faculty of Medicine, YARSI University, Jalan Letjen. Suprapto Kav.13, Cempaka Putih, Central \\ Jakarta, Jakarta, Indonesia.
}

DATA OF ARTICLE:

Received: 9 Mei 2019

Reviewed: 25 Jun 2019

Revised: 9 Oct 2019

Accepted: 25 Nov 2019

*CORRESPONDENCE: erinaerina14@yahoo.com

DOI:

10.18196/mm.200135

TYPE OF ARTICLE:

Research

\begin{abstract}
The excess of body fat in the body can be associated with the risk of diabetes, cardiovascular disease, and other metabolic diseases. Activities which can reduce the body fat percentage is a structured physical activity. This study aims to identify the effect of the structured physical activity on the decrease in body fat percentage on members of the gymnastics studio. This study used one group of pretest-posttest design. The intervention was an aerobic exercise, conducted for a minimum duration of 150 minutes per week, and followed up for three months. The samples were selected by using purposive sampling and were collected by measuring the respondent's weight with Bioelectrical Impedance Analysis at the beginning and the end of this study. The data were analyzed by using paired sample t-test. The result showed that the average of the body fat percentage on the pre-test was $33.156 \%$, and on the post-test was $32.920 \%$. Based on the data, there was a decrease in a bodyfat percentage on pre-test and post-test in 13 out of 25 respondents. The $p$-value was 0.357 , and it can be concluded that the structured physical activity did not have a significant effect on the decrease in body fat percentage.
\end{abstract}

Keywords: Body fat percentage; Female; Gymnastic studio; Structured physical activity

\begin{abstract}
Abstrak: Kelebihan lemak dalam tubuh dapat dikaitkan dengan risiko diabetes, penyakit kardiovaskular, dan penyakit metabolisme lainnya. Aktivitas yang dapat mengurangi persentase lemak tubuh adalah aktivitas fisik terstruktur. Penelitian ini bertujuan untuk mengidentifikasi pengaruh aktivitas fisik terstruktur terhadap penurunan persentase lemak tubuh pada anggota sanggar senam. Penelitian ini menggunakan desain satu kelompok pretest-posttest. Intervensi yang diberikan berupa latihan aerobic yang dilakukan dengan durasi minimum 150 menit per minggu selama tiga bulan. Sampel dipilih menggunakan purposive sampling dan dikumpulkan dengan mengukur berat responden dengan Analisis Impedansi Bioelektrik pada awal dan akhir penelitian. Data dianalisis menggunakan paired sample t-test. Hasil penelitian menunjukkan bahwa rata-rata persentase lemak tubuh pada pre-test adalah 33.156\%, dan pada post-test adalah 32.920\%. Berdasarkan data, ada penurunan persentase lemak tubuh pada pre-test dan post-test di 13 dari 25 responden. Didapatkan p=0.357, sehingga dapat disimpulkan bahwa aktivitas fisik terstruktur tidak memiliki pengaruh yang signifikan terhadap penurunan persentase lemak tubuh.
\end{abstract}

Kata Kunci: Persentase lemak tubuh; Perempuan; Sanggar senam; Aktivitas fisik terstruktur 


\section{INTRODUCTION}

Physical activity is known to play an important role in preventing obesity and the distribution of body fat. ${ }^{1}$ Based on the research by Rachmi et al. in 2017, ${ }^{2}$ Referring to the Basic Health Research (Riskesdas) data in 2007 and 2010, it showed that the prevalence of 19 to 55-year-old overweight or obese adults increased from $19.8 \%$ in 2007 to $23 \%$ in 2010 , with the highest prevalence in women compared to men in the second year. One of the risk factors of obesity is a lack of physical activities. ${ }^{2}$ The excess of body fat in organs can be associated with the risk of diseases such as diabetes, cardiovascular disease, and other metabolic diseases. ${ }^{3}$ The decrease in visceral fat mass has a significant relationship with a risk reduction of coronary heart disease. ${ }^{4}$

The proportion of the less significant physical activity, in general, is $26.1 \%$ based on the data from Basic Health Research (Riskedas) in 2013. The criteria for significant physical activity are individuals who perform heavy or moderate physical activity or both. Meanwhile, the criteria for less significant physical activity are individuals who do not carry out either moderate or substantial physical activity. The result showed an increase in the number of obese adults with the highest prevalence in women. One risk factor of obesity is a lack of physical activity. DKI Jakarta is one of the highest provinces with a population with less significant physical activity, with a total of $44.2 \%{ }^{5}$

An exercise is an inexpensive activity, free from pharmacological elements, and is useful for the transformation of body composition and can reduce cardiometabolic risk. It is such a powerful strategy for fat reduction, especially abdominal visceral fat. ${ }^{6}$ The recommended exercise program to improve physical fitness is CRIPE (continuous, rhythmical, interval, progressive, endurance). The 50 to 60-minute perpetual physical exercise was conducted rhythmically within a specified interval by gradually increasing weight training to improve the freshness and endurance of the cardiovascular system.?

Several exercises that can be applied in daily life are such as aerobics, cycling, Zumba, modern dance, and so on. ${ }^{8}$ Research conducted by Irving et al. in $2018,{ }^{6}$ showed that physical activity is effective in reducing body fat percentage, fat mass, waist circumference, and abdominal circumference in obese adults. it is interesting to research the effect of structured physical activity on the decrease in the percentage of body fat in gym members.

\section{MATERIALS AND METHOD}

This research is an experimental study with one group pretest-posttest design. This research was conducted by giving treatment in the form of physical activity in one group of respondents without a control group for three months. Measurement of the respondent's body fat percentage was carried out within pre and posttreatment. The population and sample were members of the $\mathrm{R}$ and $\mathrm{K}$ gymnastics studios in Cempaka Putih and Johar Baru, in November 2017 until January 2018.

The inclusion criteria in this study included members of the gymnastics studio who were 18-60 years old. Meanwhile, the exclusion criteria were those who were not willing to take part in this study for three months and were pregnant. Then, the sample was selected using nonprobability sampling, namely purposive sampling, and then 36 respondents were obtained while 11 respondents dropped out. Data collection was carried out by conducting interview and observation to record the frequency of respondents' physical activity as well as the habits of the respondents such as a diet program, Monday-Thursday fasting habits, and exercise habits other than the one examined in this study and physical examination of body weighing to identify the percentage of body fat in the beginning and the end of the study. The method of body weighing was conducted in a way that the respondent was barefoot, looked straight ahead, with the position of the hand holding one part of the weighing tool, and stood upon the weighing tool until it showed the body fat percentage automatically. Bivariate analysis in this study used a paired t-test.

\section{RESULT}

This research was conducted on two groups of females at the R gymnastics studio in Cempaka Putih and $\mathrm{K}$ gymnastics in Johar Baru, with a total of 36 respondents. The respondents carried out a structured physical activity such as aerobics for at least 150 minutes per week for 12 weeks. During the study, four people resigned, and seven people did not fit the inclusion criteria and that the number of samples that could be monitored for three months was 25 people. Measurements were taken twice at the beginning and the end of the twelfth week. Table 1 showed the respondents' characteristic. Table 2 showed the results of body fat percentage at pre and post treatment and Table 3 showed the T-test analysis result. 
Table 1. The Respondents' Characteristic

\begin{tabular}{lcc}
\hline Characteristic & Frequency & Pecentage (\%) \\
\hline Age $(\mathbf{y} \cdot \mathbf{o})$ & & \\
Late adolescent $(17-25)$ & 5 & 20 \\
Early adulthood $(26-35)$ & 3 & 12 \\
Late adulthood $(36-45)$ & 13 & 52 \\
Early elderly $(46-55)$ & 4 & 16 \\
Body Mass Index $\left(\mathbf{k g} / \mathbf{m}^{2}\right)$ & & \\
Underweight $(<18.5)$ & 0 & 0 \\
Normal-weight $(18.5-22.9)$ & 6 & 24 \\
Overweight $(23-24.9)$ & 6 & 24 \\
Obese $(\geq 25)$ & 13 & 52 \\
\hline
\end{tabular}

Table 2. The Results of Body Fat Percentage at Pre and Post Treatment

\begin{tabular}{lcccc}
\hline \multirow{2}{*}{ Classification } & \multicolumn{5}{c}{ Body Fat Percentage } \\
\cline { 2 - 5 } & \multicolumn{2}{c}{ Pre test } & \multicolumn{3}{c}{ Post test } \\
\cline { 2 - 5 } & $\mathrm{F}$ & $\%$ & $\mathrm{~F}$ & $\%$ \\
\hline 20-40 years old & & & & \\
Underfat $(<21)$ & 0 & 0 & 0 & 0 \\
Healthy (21-33) & 10 & 40 & 9 & 36 \\
Overweight (33-39) & 3 & 12 & 4 & 16 \\
Obese (>39) & 1 & 4 & 1 & 4 \\
41-60 years old & & & & \\
Underfat $(<23)$ & 0 & 0 & 0 & 0 \\
Healthy (23-35) & 6 & 24 & 6 & 24 \\
Overweight $(35-40)$ & 4 & 16 & 4 & 16 \\
Obese $(>40)$ & 1 & 4 & 1 & 4 \\
$\mathrm{~N}$ & 25 & 100 & 25 & 100 \\
\hline
\end{tabular}

Table 3. Distribution of T-test analysis result

\begin{tabular}{lccc}
\hline & Mean $(\%)$ & \pm SD & P-value \\
\cline { 2 - 4 } Pre-Test & 33.156 & 4.86 & \multirow{2}{*}{0.357} \\
Post-Test & 32.920 & 4.66 & \\
\hline
\end{tabular}

Based on the results in Table 1, it showed that by the age, more than half respondents were early adulthood (52\%) and classified as obese (52\%). Furthermore, Table 2 showed that even an increase in the number of respondents who experienced overweight among respondent age 20-40 years old, from 3 to 4 . The T-test analysis that shown in Table 3 revealed the value of $p=0.357(p>0.05)$.

\section{DISCUSSION}

Referring to Asian BMI criteria such as normal BMI of 18.5 to $22.9 \mathrm{~kg} / \mathrm{m}^{2}$, overweight 23 $24.9 \mathrm{~kg} / \mathrm{m}^{2}$, and obese $\geq 25 \mathrm{~kg} / \mathrm{m}^{2} .9$ The result showed that the respondents were female with a normal BMI category of $24 \%$, overweight by $24 \%$, and obese by $52 \%$. In numeral, it revealed a decrease in body fat percentage of 13 people in which three people did not change, and nine people experienced an increase in body fat percentage. Yet, based on the classification on
Table 2, there is no change in each classification except in overweight age 20-40 years actually increased from 3 to 4 . In the group of respondents who intensively underwent the physical activity examined in the study, there is an average reduction in body fat percentage of $0.236 \%$. This decrease was not statistically significant since the result of the bivariate analysis with paired t-test showed $P=0.357$, indicating that there was no influence between structured physical activity on the de body fat percentage.

The percentage of body fat can be influenced by various factors, such as food intake. The study of Lombardo et al., (2017) ${ }^{10}$ suggested that calorie restriction and exercise can reduce the percentage of fat mass. Dietary (food) interventions, in general, can produce a greater energy deficit, and it can accelerate the decrease in body mass rather than only carrying out the exercise without any dietary interventions. ${ }^{11}$ In contrast, a study found that aerobic exercise three times per week with a hypocaloric diet for changes in body composition revealing that there were no significant differences in fat mass between the group who consumed food before conducting the exercise and the group who did not. ${ }^{12}$ Another study stated that conducting an aerobic exercise for 12 weeks showed a decrease in fat mass of $1.3 \mathrm{~kg}$ and a percentage decrease of $1 \%$ in the moderate exercise respondent group without dietary intervention. The result indicates that there is no significant effect on fat mass reduction and body fat percentage. The decrease that occurred in the exercise group was not as significant as the diet group or the combination of diet and exercise group. ${ }^{13}$

In another study of the effects of diet and aerobic exercise for 12 months by comparing the exercise group, the diet group, the combination of exercise and diet group, as well as the control group. ${ }^{11}$ The result of this study showed that the combination of diet and exercise group and the diet group have a higher percentage of body fat reduction than the exercise group. ${ }^{14}$

It suggested that diet and exercise interventions for eight weeks decreased body mass index, and increased physical fitness level. However, no significant effect was found on body fat, and diet intake was the most influential variable. ${ }^{1}$ It explains why this study did not show a significant reduction in body fat percentage. It is because one of the factors affecting the body fat was diet and food intake controls, which were not carried out in this study.

Based on the result of the interview, all respondents did not have a significant difference in the diet condition. Rice and side dishes such as 
chicken, eggs, vegetables, and fruit become their daily food. However, the frequency and portion of the food are undoubtedly different from one person to another. Half of the total respondents who experienced a decrease in body fat percentage often underwent Monday-Thursday fasting every week.

In the group that experiences an increase in body fat percentage, most respondents did not undergo Monday-Thursday fasting and were identified to consume food after the exercise frequently. In this case, fasting plays an important role since, during the fasting activity, our bodies absorb energy sources from fatty acids produced by adipocytes to reduce the percentage of body fat. ${ }^{15}$

Furthermore, another factor is physical activity. Physical activity is associated with a lower BMI and a low percentage of body fat. Thus, the higher the level of physical activity is, the lower the percentage of body fat will be. ${ }^{16}$ Based on the result of the interview, the group that experienced a decrease in the body fat percentage included workers, housewives, and students. They had more physical activities in their daily life than other respondents, such as playing basketball, doing yoga, and doing gymnastics in the studio more than 150 minutes a week.

The group that experienced an increase in the body fat percentage has a profession as housewives who did not carry out other physical activities outside of 150-minute gymnastics in the studio. It indicates that there are differences in the result of the body fat percentage at the beginning and the end of the study due to the different daily physical activities other than aerobics among the respondents. The researchers were unable to limit the daily activities carried out by the respondents during the research. Another limitation of the study is the limited sample due to various unavoidable factors from respondents, such as illness or longdistance traveling during the data collection process of the study.

\section{CONCLUSION}

Structured physical activity has no significant effect on reducing body fat percentage among gymnastics studio members.

\section{REFERENCES}

1. Anam, M. S., Mexitalia, M., Widjanarko, B., Pramono, A., Susanto, H., \& Subagio, H. W. Pengaruh Intervensi Diet dan Olah Raga Terhadap Indeks Massa Tubuh, Lemak Tubuh, dan
Kesegaran Jasmani pada Anak Obes. Sari Pediatri, 2016; 12 (1), 36-41.

2. Rachmi, C. N., Li, M., \& Baur, L. A. Overweight and obesity in Indonesia: prevalence and risk factors-a literature review. Public Health, 2017; 147: 20-29.

3. Kwon, H. R., Min, K. W., Ahn, H. J., Seok, H. G., Koo, B. K., Kim, H. C., \& Han, K. A. Effects of aerobic exercise on abdominal fat, thigh muscle mass and muscle strength in type 2 diabetic subject. Korean diabetes journal, 2010; 34 (1): 23-31.

4. Tong, T. K., Zhang, H., Shi, H., Liu, Y., Ai, J., Nie, J., \& Kong, Z. Comparing time efficiency of sprint vs. high-intensity interval training in reducing abdominal visceral fat in obese young women: a randomized, controlled trial. Frontiers in physiology, 2018; 9: 1048.

5. Kemenkes, R. I. Riset kesehatan dasar 2013. Ministry of Health Republic of Indonesia, 2013, 1, 1303. Retrivied on September 8th, 2017, from http://www.depkes.go.id/resources/download/gen eral/Hasil\%20Riskesdas\%202013.pdf.

6. Maillard, F., Pereira, B., \& Boisseau, N. Effect of high-intensity interval training on total, abdominal and visceral fat mass: a meta-analysis. Sports Medicine, 2018; 48 (2): 269-288.

7. Sinaga, R. N. Diabetes mellitus dan Olahraga. Jurnal Ilmu Keolahragaan, 2016; 15 (2): 21-29.

8. Schiff, N. T. Dampak Aktivitas Senam Aerobik, Tari Zumba, dan Tari Jaipong terhadap Perubahan Kadar Lemak Tubuh. (Doctoral dissertation, Universitas Pendidikan Indonesia). 2014.

9. Douglas G, Nicol F, Robertson C. Pemeriksaan Klinis Macleod. Edisi Ketigabelas. London: Elsevier. 2014.

10. Lombardo, M., Magarotto, R., Marinelli, F., Padua, E., Caprio, M., Annino, G., ... \& Iellamo, F. Ideal reduction of calories for greatest reduction of body fat and maintenance of lean body mass. The Journal of Aging Research and Clinical Practice, 2017; 1(1):1-6.

11. Tomlinson, D. J., Erskine, R. M., Morse, C. I., \& Onambélé, G. L. Body fat percentage, body mass index, fat mass index and the ageing bone: their singular and combined roles linked to physical activity and diet. Nutrients, 2019; 11 (1): 195.

12. Schoenfeld, B. J., Aragon, A. A., Wilborn, C. D., Krieger, J. W., \& Sonmez, G. T. Body composition changes associated with fasted versus non-fasted aerobic exercise. Journal of the International Society of Sports Nutrition, 2014; 11 (1): 1-7.

13. Frimpong, E., Dafkin, C., Donaldson, J., Millen, A. M. E., \& Meiring, R. M. The effect of home-based low-volume, high-intensity interval training on cardiorespiratory fitness, body composition and cardiometabolic health in women of normal body mass and those with overweight or obesity: protocol 
for a randomized controlled trial. BMC Sports Science, Medicine and Rehabilitation, 2019; 11 (1): 39.

14. Foster Schubert, K. E., Alfano, C. M., Duggan, C. R., Xiao, L., Campbell, K. L., Kong, A., ... \& McTiernan, A. Effect of diet and exercise, alone or combined, on weight and body composition in overweight to obese postmenopausal women. Obesity, 2012; 20 (8): 1628-1638.
15. Syam, A. F., Sobur, C. S., Abdullah, M., \& Makmun, D. Ramadan fasting decreases body fat but not protein mass. International journal of endocrinology and metabolism, 2016; 14 (1): e29687.

16. Bradbury, K. E., Guo, W., Cairns, B. J., Armstrong, M. E., \& Key, T. J. Association between physicall activity and body fat percentage, with adjustment for BMI: a large cross-sectional analysis of UK Biobank. BMJ open, 2017; 7 (3): e011843. 